\title{
Efficacy of stomach-partitioning on gastric emptying in patients undergoing palliative gastrojejunostomy for malign gastric outlet obstruction
}

\author{
다 Reyyan Yıldırım, M.D., ${ }^{1}$ (1) Bahar Candaş, PhD., ${ }^{2}$ ㄴ) Mehmet Arif Usta, M.D., ${ }^{1}$

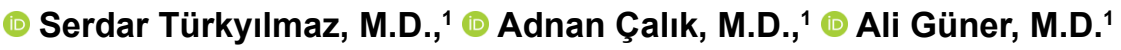

\author{
1'Department of General Surgery, Karadeniz Technical University Faculty of Medicine, Trabzon-Turkey \\ ${ }^{2}$ Department of Surgical Disease Nursing, Karadeniz Technical University Faculty of Health Sciences, Trabzon-Turkey
}

\begin{abstract}
BACKGROUND: Palliative efficacy of conventional gastrojejunostomy in palliation of malignant gastric outlet obstruction is debatable. This study aims to compare the outcomes of conventional gastrojejunostomy and stomach-partitioning gastrojejunostomy and to explore the factors influencing the delayed gastric emptying after surgery in patients with malignant gastric outlet obstruction.

METHODS: The study subjects were divided into the following two groups based on whether the stomach was partitioned or not: Conventional gastrojejunostomy and stomach-partitioning gastrojejunostomy. All demographic data, patient characteristics, postoperative outcomes, including delayed gastric emptying grade and 30-day complications were collected. Following the comparison of the clinical outcomes, risk factors for delayed gastric emptying were determined by regression models.

RESULTS: Fifty-three patients were included in this study. Of these, 37 patients underwent conventional gastrojejunostomy, whereas 16 patients underwent stomach-partitioning gastrojejunostomy. Patient demographics and baseline characteristics were comparable between groups. Although 10 (27\%) patients in the conventional gastrojejunostomy group had delayed gastric emptying grade B-C, no patient in the stomach-partitioning gastrojejunostomy group experienced this condition. There was no difference between the groups concerning hospital stay and complications. In multivariate regression analysis, having distant metastasis $(\mathrm{OR}=0.156,95 \% \mathrm{Cl}$ $0.034-0.720, p=0.017)$ and stomach-partitioning $(O R=0.127,95 \% \mathrm{Cl} 0.025-0.653, p=0.014)$ were found as independent factors for the delayed gastric emptying.
\end{abstract}

CONCLUSION: In patients with malignant gastric outlet obstruction, compared with conventional gastrojejunostomy, stomach-partitioning may provide favorable clinical outcomes by improving gastric emptying.

Keywords: Delayed gastric emptying; gastric outlet obstruction; stomach-partitioning gastrojejunostomy.

\section{INTRODUCTION}

Gastric outlet obstruction (GOO) is a clinical syndrome that arises because of any benign or malignant process leading to an obstruction at the level of the stomach outlet. ${ }^{[1-3]}$ Symptoms of GOO can be the main impediment in attaining a better quality of life by patients. Although the traditional treatment choice for GOO is gastrojejunostomy (GJ), less invasive endoscopic treatment options, such as dilatation and endolu- minal stenting, have also been used. ${ }^{[4,5]}$ However, owing to the possibility of long-term stent-related complications, surgical GJ is usually recommended as a palliative option for patients with long-life expectancy. ${ }^{[6-8]}$ Conventional GJ is commonly performed with side-to-side loop jejunal anastomosis to the proximal part of the obstruction; however, studies have demonstrated that conventional GJ may not provide acceptable palliation in some patients because of impaired gastric emptying. ${ }^{[9,10]}$ According to recent reports, up to $47 \%$ of the

Cite this article as: Yıldırım R, Candaş B, Usta MA, Türkyılmaz S, Çalık A, Güner A. Efficacy of stomach-partitioning on gastric emptying in patients undergoing palliative gastrojejunostomy for malign gastric outlet obstruction. Ulus Travma Acil Cerrahi Derg 2020;26:678-684.

Address for correspondence: Ali Güner, M.D.

Karadeniz Teknik Üniversitesi Tıp Fakültesi, Genel Cerrahi Anabilim Dalı, Trabzon, Turkey

Tel: +90 462 - 37756 I3 E-mail: draliguner@yahoo.com

Ulus Travma Acil Cerrahi Derg 2020;26(5):678-684 DOI: 10.14744/tjtes.2020.14668 Submitted: 27.09.2019 Accepted: 27.01.2020 Online: 09.09.2020

Copyright 2020 Turkish Association of Trauma and Emergency Surgery 
patients experienced delayed gastric emptying (DGE) after conventional G]; therefore, the palliative efficacy of conventional $\mathrm{G}]$ is debatable. ${ }^{[11,12]}$

Stomach-partitioning GJ (SPGJ) has been developed to improve the outcomes of the GJ procedure. ${ }^{[12-14]}$ In this technique, the stomach is partially partitioned to eliminate the risk of a blowout of the closed-loop in the distal stomach. ${ }^{\left[{ }^{1 !}\right]}$ There are some case series that have assessed the efficacy of SPG]. ${ }^{[14-17]}$ Besides, some comparative studies suggested that SPGJ may improve DGE compared to conventional G]. ${ }^{[1-13]}$ However, patients included in the studies had various clinicopathological features that may have the potential to influence the outcomes. Improvement of DGE was evaluated only by considering the type of $G$ J, without considering other crucial factors.

In this study, we aimed to compare the outcomes of conventional and stomach-partitioning $\mathrm{G}$ J and to explore the factors influencing the DGE in patients undergoing palliative gastrojejunostomy for malign GOO.

\section{MATERIALS AND METHODS}

\section{Patients and Data Collection}

We retrospectively reviewed the electronic medical records of patients who underwent a bypass for $\mathrm{GOO}$ between March 2013 and February 2019. GOO is diagnosed based on recurrent symptoms of epigastric abdominal pain and postprandial vomiting that arose from mechanical obstruction confirmed radiologically (upper gastrointestinal series or contrast-enhanced computerized tomography) or endoscopically at the level of the stomach outlet. The GOO score was calculated based on a scoring system defined by Adler (GOO score: $0=$ no oral feed, I = liquids only, 2 = soft solids, and 3 = complete diet). ${ }^{[l]}$ The main inclusion criteria were a GOO score of $0-2$ and having undergone only $\mathrm{GJ}$ without any resection as surgical treatment. Of the 64 patients treated with GJ, patients with benign disease $(n=2)$ and who underwent concomitant biliary bypass during the same surgical procedure $(n=9)$ were excluded from the analyses.

All the data regarding patient demographics and preoperative clinical data were collected. Comorbidities were evaluated using the Charlson comorbidity index $(\mathrm{CCl}) .{ }^{[18]}$ Postoperative short-term outcomes, including the length of hospital stay, postoperative GOO score, and the presence of DGE, DGE grade, complications, and operative mortality were also collected. Postoperative GOO scores were assessed approximately two weeks after surgery. The primary outcome of this study was the presence of DGE, and the DGE grade was calculated based on the grading system defined by the International Study Group of Pancreatic Surgery (nasogastric tube requirement and ability to tolerate foods are used). ${ }^{[19]}$ Grades B and C were defined as clinically significant DGE. Prolonged hospitalization was defined as a hospital stay longer than 10 days. Adverse events occurring within 30 days of the surgery (or within the hospitalization period for patients who stayed in the hospital for $>30$ days) were classified as postoperative complications and were classified according to the Clavien-Dindo classification system. ${ }^{[20]}$ Complications of $\geq$ grade 3 were classified as major. Mortality occurring within 30 days after the surgery was defined as operative mortality. Signed informed consent was obtained from all patients before surgery. Ethical permission for this study was obtained from the ethical committee.

\section{Surgical Procedures}

In this study population, conventional GJ was performed using two reconstruction techniques. In both the techniques, the proximal jejunal loop was anastomosed to the stomach (side-to-side manner and at least $3-5 \mathrm{~cm}$ proximal from the distal tumor) using a single, $60-\mathrm{mm}$ linear stapling device via the conventional loop Billroth-II GJ technique (Fig la). For conventional Roux-en-Y GJ, in addition to the loop GJ technique, the ascending part of the jejunal limbs was divided just before the $\mathrm{GJ}$ anastomosis site and anastomosed to the descending part of the jejunum, $25-30 \mathrm{~cm}$ distal to the GJ anastomosis using a stapling device (Fig lb) ${ }^{[21]}$ For SPG], the stomach was partially divided using linear stapling devices from the greater curvature side of the proximal stomach, and $\mathrm{I}-2 \mathrm{~cm}$ from the lesser curvature side was left undivided. After gastric division, $G$ J was performed with a linear stapling device in Roux-en-Y fashion, as previously described (Fig. 2). ${ }^{\left[{ }^{\prime \prime}\right]}$ For the laparoscopic surgery, a similar technique was used using five ports, and all anastomoses were completed intracorporeally with linear stapling devices. ${ }^{[22]}$ The decision for reconstruction technique and approach was decided based on the surgeon's preference.

\section{Statistics and Ethics}

Continuous variables are presented as mean \pm standard deviation for the parametric distribution and as median (25th-75th percentile) for the nonparametric distribution. Chi-square test or Fisher exact test, Student's t-test and Mann-Whitney

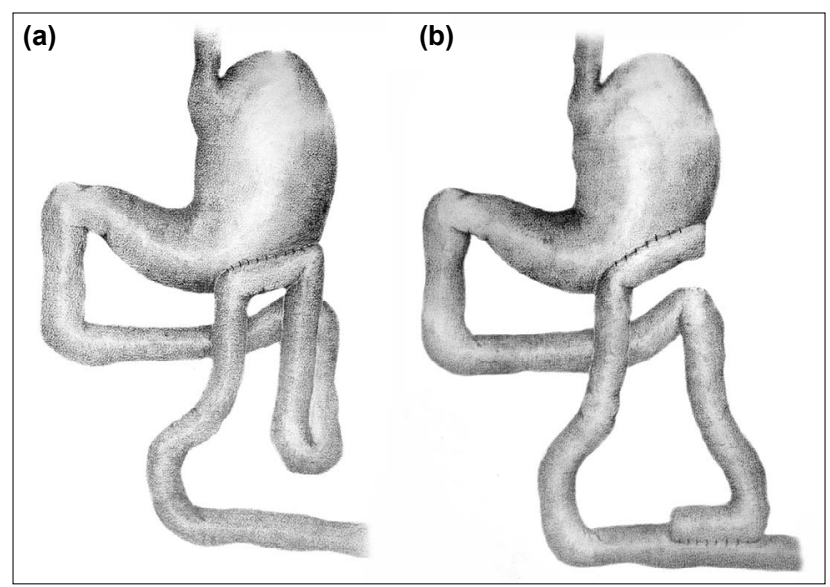

Figure 1. Schematic illustrations of conventional gastrojejunostomy. (a) Billroth-II gastrojejunostomy; (b) Roux-en-Y gastrojejunostomy. 


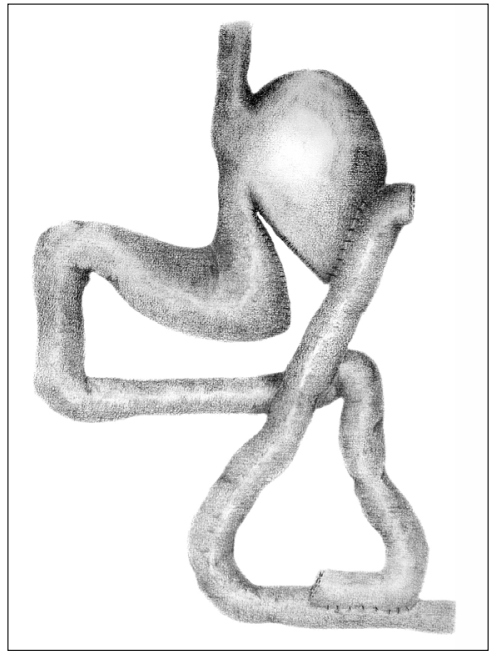

Figure 2. Schematic illustration of Roux-en-Y stomach-partitioning gastrojejunostomy.

test were used for comparing the groups based on the type and characteristics of the data. The linearity of the continuous variables concerning the logit of the dependent variable was assessed. ${ }^{[23]}$ Based on this assessment, all continuous variables except for age were found to be linearly related to the logit of the dependent variable. For univariate analyses, a binary logistic regression test was used. All potential confounding factors were entered into the multivariate logistic regression model using a backward stepwise approach to explore the risk factors for the presence of the DGE. All p-values were two-sided, and statistical significance was defined as $P<0.05$. R software ( $R$ Foundation for Statistical Computing, Vienna, Austria) with required packages was used for statistical analyses.

\section{RESULTS}

Fifty-three patients who met the criteria were included in the analyses. Of these, 37 patients underwent conventional GJ, whereas 16 patients underwent SPGJ. Patient demographics and baseline characteristics were comparable between the groups (Table I). For operative data, two patients in the SPGJ group underwent laparoscopic surgery while an open

Table I. Patient demographics and baseline characteristics

\begin{tabular}{|c|c|c|c|}
\hline Variables & Conventional GJ $(n=37)$ & Stomach-partitioning $G J(n=16)$ & p-value \\
\hline Age (years), mean $\pm S D$ & $68.7 \pm 14.4$ & $62.7 \pm 10.2$ & 0.135 \\
\hline \multicolumn{4}{|l|}{ Sex, n (\%) } \\
\hline Male & $25(67.6)$ & II (68.8) & 0.933 \\
\hline Female & $12(32.4)$ & $5(31.2)$ & \\
\hline Charlson comorbidity index, mean $\pm S D$ & $5.9 \pm 2.3$ & $5.1 \pm 2.4$ & 0.287 \\
\hline Hemoglobin $(g / d L)$, mean $\pm S D$ & $11.3 \pm 2.3$ & $11.3 \pm 1.8$ & 0.969 \\
\hline Albumin $(g / d L)$, mean $\pm S D$ & $3.3 \pm 0.6$ & $3.4 \pm 0.6$ & 0.470 \\
\hline \multicolumn{4}{|l|}{ Preoperative transfusion, n (\%) } \\
\hline No & $28(75.7)$ & $13(81.2)$ & 0.656 \\
\hline Yes & $9(24.3)$ & $3(18.8)$ & \\
\hline \multicolumn{4}{|l|}{ Origin of malignancy, n (\%) } \\
\hline Gastroduodenal & $20(54.1)$ & $13(81.2)$ & 0.061 \\
\hline Pancreaticobiliary & $17(45.9)$ & $3(18.8)$ & \\
\hline \multicolumn{4}{|l|}{ Reason for non-resection, $\mathrm{n}(\%)$} \\
\hline Locally-advanced & $25(67.6)$ & $10(62.5)$ & 0.721 \\
\hline Distant metastasis & $12(32.4)$ & $6(37.5)$ & \\
\hline \multicolumn{4}{|l|}{ Preoperative chemotherapy, n (\%) } \\
\hline No & $33(89.2)$ & $13(81.2)$ & 0.419 \\
\hline Yes & $4(10.8)$ & $3(18.8)$ & \\
\hline \multicolumn{4}{|l|}{ Preoperative GOO score, n (\%) } \\
\hline Score 0 & $19(51.4)$ & $7(43.8)$ & 0.729 \\
\hline Score I & $12(32.4)$ & $7(43.8)$ & \\
\hline Score 2 & $6(16.2)$ & $2(12.4)$ & \\
\hline \multicolumn{4}{|l|}{ Approach, n (\%) } \\
\hline Open & $37(100)$ & $14(87.5)$ & 0.087 \\
\hline Laparoscopy & - & $2(12.5)$ & \\
\hline
\end{tabular}

Data were presented as mean \pm standard deviation or number of patients (percentage). GJ: Gastrojejunostomy; GOO: Gastric outlet obstruction; SD: Standard deviation. 
approach was used in all remaining patients; there was no statistically significant difference between groups concerning the approach. All patients in the SPGJ group underwent Roux-en-Y reconstruction, while 21 (56.8\%) patients in the conventional GJ group underwent Roux-en-Y reconstruction.

Postoperative clinical outcomes are presented in Table 2. There was no difference between the groups concerning the length of hospital stay, all complication rate, major complication rate, reoperation rate, and operative mortality. Three patients required reoperation, all belonging to the conventional GJ group. One patient had ongoing GOO-related concerns; therefore, Billroth-II was converted to Roux-en-Y reconstruction. One patient experienced anastomotic leakage and was operated again. One patient was re-operated because of intraabdominal bleeding (bleeding from the gastroepiploic vessels) for hemostasis. Although there was no statistically significant difference concerning operative mortality among the groups, operative mortality was observed in four patients $(10.8 \%)$ in the conventional GJ group. The mean age and the mean $\mathrm{CCl}$ score were $83.5 \pm 3.8$ years and $8.3 \pm 2$. I in patients experienced operative mortality, respectively. In patients without operative mortality, the mean age and the mean $\mathrm{CCl}$ score were $65.6 \pm 13.1$ years and $5.5 \pm 2.3$, respectively. There was a statistically significant difference between the patients who experienced the operative mortality or did not, concerning the age $(p=0.009)$ and the $C C l$ score $(p=0.022)$.

Post-operative GOO scores, the incidence of DGE and DGE grades differed between the groups. Two weeks after surgery, all patients in the SPGJ group were able to eat soft solids or complete diet, while $24.3 \%(9 / 37)$ of patients in the conventional GJ group still had a GOO score of 0 or I.

Incidences of DGE in the conventional GJ group and SPGJ group were $70.3 \%$ and $18.8 \%$, respectively. No patients in the SPGJ group experienced clinically significant DGE (grade B or C), while $10(27 \%)$ of the patients in the conventional group experienced clinically significant DGE.

Univariate regression analysis demonstrated that the presence of distant metastasis rather than locally-advanced malignancy as a reason for non-resection, Roux-en- $Y$ reconstruction rather than Billroth-II reconstruction and stomach-partitioning are better prognostic factors for the DGE (Table 3). In multivariate regression analysis, having distant metastasis $(\mathrm{OR}=0.156,95 \% \mathrm{Cl} 0.034-0.720, \mathrm{p}=0.017)$ and stomach-partitioning $(\mathrm{OR}=0.127,95 \% \mathrm{Cl} 0.025-0.653, \mathrm{p}=0.014)$ were found as independent factors for the DGE.

\section{DISCUSSION}

In the present study, we compared the outcomes of conventional and stomach-partitioning $\mathrm{GJ}$ in the palliation of malignant GOO and also explored the factors influencing the DGE after surgical treatment of the GOO. We found that SPGJ may provide satisfactory postoperative GOO scores and may decrease the incidence of the DGE after surgery. Although the SPGJ group showed exceptional improvement in the ability of oral feeding, complication rates and hospital stay were comparable between the two groups. We also found that the presence of the unresectable locally-advanced malignancy regardless of the origin increased the incidence of the DGE.

Table 2. Postoperative clinical outcomes

\begin{tabular}{|c|c|c|c|}
\hline Variables & Conventional GJ $(n=37)$ & Stomach-partitioning GJ $(n=16)$ & p-value \\
\hline Hospital stay (days) & $8(7-14)$ & $8(8-10)$ & 0.822 \\
\hline Prolonged hospitalization, n (\%) & $13(35.1)$ & $3(18.8)$ & 0.233 \\
\hline All complications, n (\%) & $15(40.5)$ & $6(37.5)$ & 0.835 \\
\hline Major complications, n (\%) & $9(24.3)$ & I (6.3) & 0.123 \\
\hline Reoperation, n (\%) & $3(8.1)$ & - & 0.545 \\
\hline Operative mortality, n (\%) & $4(10.8)$ & - & 0.303 \\
\hline \multicolumn{4}{|l|}{ Postoperative GOO score, n (\%) } \\
\hline Score 0-1 & $9(24.3)$ & - & 0.030 \\
\hline Score 2-3 & $28(75.7)$ & $16(100)$ & \\
\hline Presence of DGE, n (\%) & $26(70.3)$ & $3(18.8)$ & 0.001 \\
\hline \multicolumn{4}{|l|}{ Grades of DGE, n (\%) } \\
\hline No & II (29.7) & $13(81.2)$ & 0.006 \\
\hline Grade A & $16(43.2)$ & $3(18.8)$ & \\
\hline Grade B & $4(10.8)$ & - & \\
\hline Grade C & $6(16.2)$ & - & \\
\hline
\end{tabular}

Data were presented as median ( $25^{\text {th }}-75^{\text {th }}$ percentile) or number of patients (percentage). GJ: Gastrojejunostomy; GOO: Gastric outlet obstruction; DGE: Delayed gastric emptying. 
Table 3. Regression analysis of risk factors for delayed gastric emptying

\begin{tabular}{|c|c|c|c|c|c|}
\hline \multirow[t]{2}{*}{ Variables } & & \multicolumn{2}{|c|}{ Univariate analysis } & \multicolumn{2}{|c|}{ Multivariate analysis } \\
\hline & & OR $(95 \% \mathrm{Cl})$ & p-value & OR $(95 \% \mathrm{Cl})$ & p-value \\
\hline Age & $<70$ vs. $\geq 70$ & $1.556(0.517-4.680)$ & 0.432 & & \\
\hline Sex & male vs. female & $0.900(0.283-2.863)$ & 0.858 & & \\
\hline Charlson comorbidity index & & $0.932(0.740-1.173)$ & 0.548 & & \\
\hline Hemoglobin & & $0.929(0.716-1.204)$ & 0.576 & & \\
\hline Albumin & & $0.570(0.222-1.462)$ & 0.242 & & \\
\hline Preoperative transfusion & no vs. yes & $0.783(0.216-2.840)$ & 0.709 & & \\
\hline Origin of malignancy & PB vs GD & $0.982(0.322-2.997)$ & 0.974 & & \\
\hline Reason for non-resection & $\begin{array}{l}\text { locally-advanced vs. distant } \\
\text { metastasis }\end{array}$ & $0.261(0.078-0.869)$ & 0.029 & $0.156(0.034-0.720)$ & 0.017 \\
\hline Preoperative chemotherapy & no vs. yes & $0.28 \mathrm{I}(0.049-1.606)$ & 0.154 & & \\
\hline Preoperative GOO score & Score 0 -I vs. score 2 & $0.438(0.093-2.063)$ & 0.297 & & \\
\hline Type of reconstruction & Billroth-II vs. Roux-en-Y & $0.176(0.043-0.723)$ & 0.016 & & \\
\hline Stomach-partitioning & Conventional vs. SP & $0.098(0.023-0.412)$ & 0.001 & $0.127(0.025-0.653)$ & 0.014 \\
\hline
\end{tabular}

GOO: Gastric outlet obstruction; PB: Pancreaticobiliary; GD: Gastroduodenal; SP: Stomach-partitioning; OR: Odds ratio; CI: Confidence interval.

We found that no patients in the SPG] group experienced clinically significant DGE, although $27 \%$ of the patients in the conventional group showed clinically significant DGE. Besides, nine patients $(24.3 \%)$ in conventional GJ group were unable to eat soft/complete diet two weeks after the surgery and all required additional nutritional support after discharge, while no patients in the SPGJ group required supplemental nutrition. In the theoretical basis of SPGJ, stomach partitioning may facilitate the direct passage from the proximal stomach to the jejunum. Previous reports, including two meta-analyses of retrospective series, support this theory and have shown that stomach-partitioning alleviates DGE, and patients who have undergone stomach-partitioning may tolerate oral intake better without GOO recurrence. ${ }^{[9,13,24,25]}$ However, because the DGE may be attributable to multiple clinicopathological features, we aimed to move the current evidence one step forward. Type of reconstruction has been found as a prognostic factor in univariate analysis; however, it lost its prognostic power after adjustment for other factors. This finding contradicts the studies reporting that Roux-en-Y is superior to Billroth-II reconstruction following distal gastrectomy. ${ }^{[26,27]}$ However, we only used Roux-en-Y reconstruction in the SPGJ group, and the surgeon's preference may have caused a misinterpretation of the results. Multivariate analysis showed that there are two prognostic factors for the DGE. First, patients who have the locally-advanced disease may experience DGE more than the patients who underwent palliative surgery due to distant metastasis. Second, regardless of the reconstruction technique, stomach-partitioning, which is a surgically modifiable factor, provides better gastric emptying outcomes. We believe that, for a better understanding of the underlying causes of DGE following palliative GJ, patient- and tumor-related factors should be evaluated in further studies.
A meta-analysis has evaluated the influence of stomach-partitioning on postoperative complications. ${ }^{[9]}$ Although there was a trend toward a decrease in the incidences of complications in the SPGJ group, there was not a significant difference between treatment arms. In the present study, correspondingly, we found no difference between the two groups concerning the complications despite the decrease in number in the SPGJ group. From the technical perspectives, because the distinction between two techniques is only dividing the stomach partially with a linear stapler device, an increase in surgical complication rates is unexpected. Besides, because the SPGJ has the potential to decrease the reintervention rates, a decrease in the incidence of the complication can be expected. However, there is no evidence demonstrating less complication in the SPGJ group, so far. Current studies, including our study, possibly have an insufficient sample size for detecting an effect and lead to false-negative outcomes. Large-scale studies with sufficient power are warranted to answer this question. We believe that published studies so far can be considered as a part of the development stage (Stage 2a) of the IDEAL framework, and because the safety and efficacy have been demonstrated in the studies, it is now time to move forward to the exploration stage (Stage 2b). ${ }^{[28]}$

Unlike in previous studies, the operative mortality rates in our study were high. ${ }^{[14,15,22]}$ In total, 4 (7.5\% of all cohort) patients died in the 30-day postoperative period, and the higher mortality rate in our study warrants further evaluation and should be highlighted. Because the number of events is low, it was not possible to analyze the predictive factors for mortality in the presented study. However, we analyzed some patient characteristics and found that, for the patients who experienced operative mortality, the mean age was 
83.5 years ( 65.6 for those who survived), and the mean $\mathrm{CCl}$ score was 8.3 ( 5.5 for those who survived). None of them had a surgery-related complication and all died because of systemic complications and comorbid diseases unrelated to the surgery. Although we found no difference concerning the mortality between the groups, the presented outcomes underline the importance of patient selection for surgical palliation in the decision-making process. Although the current treatment guidelines for malignant GOO recommend GJ over endoluminal stenting in patients with a reasonable prognosis, we believe that endoscopic treatment options may be preferred in the elderly population, particularly for unfit patients. ${ }^{[8]}$

The retrospective nature and relatively small sample size were the main limitations of the presented study. With the increasing use of endoscopic treatment modalities and neoadjuvant treatment options, the number of patients requiring surgical bypass has decreased over time. In addition to the reduction in the number of patients requiring surgical palliation, deciding bypass during surgery makes it impossible to obtain the informed consent of patients. Such obstacles make it difficult to conduct an appropriate prospective randomized study; therefore, it will be challenging to obtain high-level evidence in the era of retrospective series. Besides, a systematic difference between the baseline characteristics of the groups is inevitable in non-randomized studies. Although patient demographics and baseline characteristics are comparable in the presented study, adding a multivariable regression analysis provided us independence of the groups for proper evaluation of risk factors for the DGE.

There are some published series demonstrating the benefits of the stomach-partitioning; however, to our knowledge, this is the first study analyzing multiple factors that have the potential to influence gastric emptying after surgery. Despite the presented valuable findings, we believe that there are some core outcomes, such as the quality of life, hospital-free survival, tumor bleeding in follow-up, and using stomach-partitioning as a part of neoadjuvant treatment, to be answered in future comparative studies.

In conclusion, stomach-partitioning may provide favorable clinical outcomes by improving gastric emptying compared to conventional $\mathrm{G}$ j in patients requiring surgical palliation of GOO. However, these promising outcomes should be confirmed in future prospective comparative studies.

Ethics Committee Approval: Approved by the local ethics committee.

Peer-review: Internally peer-reviewed.

Authorship Contributions: Concept: R.Y., B.C, S.T., A.G.; Design: R.Y., B.C, S.T., A.G.; Supervision: M.A.U., S.T., A.Ç., A.G.; Fundings: A.G.; Materials: R.Y., S.T., A.Ç.; Data: R.Y., B.C., M.A.U., A.Ç., A.G.; Analysis: R.Y., B.C., A.G.; Literature search: R.Y., M.A.U., A.G.; Writing: R.Y., B.C., A.G.; Critical B.C, S.T., A.G.

Conflict of Interest: None declared.

Financial Disclosure: The authors declared that this study has received no financial support.

\section{REFERENCES}

1. Adler DG, Baron TH. Endoscopic palliation of malignant gastric outlet obstruction using self-expanding metal stents: experience in 36 patients. Am J Gastroenterol 2002;97:72-8. [CrossRef]

2. Gibson JB, Behrman SW, Fabian TC, Britt LG. Gastric outlet obstruction resulting from peptic ulcer disease requiring surgical intervention is infrequently associated with Helicobacter pylori infection. J Am Coll Surg 2000;191:32-7. [CrossRef]

3. Shone DN, Nikoomanesh P, Smith-Meek MM, Bender JS. Malignancy is the most common cause of gastric outlet obstruction in the era of $\mathrm{H} 2$ blockers. Am J Gastroenterol 1995;90:1769-70.

4. Nagaraja V, Eslick GD, Cox MR. Endoscopic stenting versus operative gastrojejunostomy for malignant gastric outlet obstruction-a systematic review and meta-analysis of randomized and non-randomized trials. J Gastrointest Oncol 2014;5:92-8.

5. Chandrasegaram MD, Eslick GD, Mansfield CO, Liem H, Richardson $\mathrm{M}$, Ahmed S, et al. Endoscopic stenting versus operative gastrojejunostomy for malignant gastric outlet obstruction. Surg Endosc 2012;26:323-9.

6. Khashab M, Alawad AS, Shin EJ, Kim K, Bourdel N, Singh VK, et al. Enteral stenting versus gastrojejunostomy for palliation of malignant gastric outlet obstruction. Surg Endosc 2013;27:2068-75. [CrossRef]

7. Jeurnink SM, Steyerberg EW, van Hooft JE, van Eijck CH, Schwartz MP, Vleggaar FP, et al. Surgical gastrojejunostomy or endoscopic stent placement for the palliation of malignant gastric outlet obstruction (SUSTENT study): a multicenter randomized trial. Gastrointest Endosc 2010;71:490-9. [CrossRef]

8. National Comprehensive Cancer Network. Gastric Cancer (Version 2.2018). Available at: http://www.nccn.org/professionals/physician_ gls/pdf/gastric.pdf. Accessed February 23, 2018.

9. Kumagai K, Rouvelas I, Ernberg A, Persson S, Analatos A, Mariosa D, et al. A systematic review and meta-analysis comparing partial stomach partitioning gastrojejunostomy versus conventional gastrojejunostomy for malignant gastroduodenal obstruction. Langenbecks Arch Surg 2016;401:777-85. [CrossRef]

10. Shyr YM, Su CH, Wu CW, Lui WY. Randomized trial of gastrojejunostomy with duodenal partition versus antrectomy in unresectable periampullary cancer. Zhonghua Yi Xue Za Zhi (Taipei) 2001;64:443-50.

11. Ernberg A, Kumagai K, Analatos A, Rouvelas I, Swahn F, Lindblad M, et al. The Added Value of Partial Stomach-partitioning to a Conventional Gastrojejunostomy in the Treatment of Gastric Outlet Obstruction. J Gastrointest Surg 2015;19:1029-35. [CrossRef]

12. Usuba T, Misawa T, Toyama Y, Ishida Y, Ishii Y, Yanagisawa S, et al. Is modified Devine exclusion necessary for gastrojejunostomy in patients with unresectable pancreatobiliary cancer?. Surg Today 2011;41:97-100. [CrossRef]

13. Oida T, Mimatsu K, Kawasaki A, Kano H, Kuboi Y, Amano S. Modified Devine exclusion with vertical stomach reconstruction for gastric outlet obstruction: a novel technique. J Gastrointest Surg 2009;13:1226-32.

14. Kwon SJ, Lee HG. Gastric partitioning gastrojejunostomy in unresectable distal gastric cancer patients. World J Surg 2004;28:365-8. [CrossRef]

15. Suzuki O, Shichinohe T, Yano T, Okamura K, Hazama K, Hirano S, et 
al. Laparoscopic modified Devine exclusion gastrojejunostomy as a palliative surgery to relieve malignant pyloroduodenal obstruction by unresectable cancer. Am J Surg 2007;194:416-8. [CrossRef]

16. Kubota K, Kuroda J, Origuchi N, Kaminishi M, Isayama H, Kawabe T, et al. Stomach-partitioning gastrojejunostomy for gastroduodenal outlet obstruction. Arch Surg 2007;142:607-11. [CrossRef]

17. Arciero CA, Joseph N, Watson JC, Hoffman JP. Partial stomach-partitioning gastrojejunostomy for malignant duodenal obstruction. Am J Surg 2006;191:428-32. [CrossRef]

18. Charlson ME, Pompei P, Ales KL, MacKenzie CR. A new method of classifying prognostic comorbidity in longitudinal studies: development and validation. J Chronic Dis 1987;40:373-83. [CrossRef]

19. Wente MN, Bassi C, Dervenis C, Fingerhut A, Gouma DJ, Izbicki JR, et al. Delayed gastric emptying (DGE) after pancreatic surgery: a suggested definition by the International Study Group of Pancreatic Surgery (ISGPS). Surgery 2007;142:761-8. [CrossRef]

20. Clavien PA, Barkun J, de Oliveira ML, Vauthey JN, Dindo D, Schulick $\mathrm{RD}$, et al. The Clavien-Dindo classification of surgical complications: five-year experience. Ann Surg 2009;250:187-96. [CrossRef]

21. Szymanski D, Durczynski A, Nowicki M, Strzelczyk J. Gastrojejunostomy in patients with unresectable pancreatic head cancer - the use of Roux loop significantly shortens the hospital length of stay. World J Gastroenterol 2013;19:8321-5. [CrossRef]
22. Kushibiki T, Ebihara Y, Hontani K, Tanaka K, Nakanishi Y, Asano T, et al. The Surgical Outcomes of Totally Laparoscopic Stomach-partitioning Gastrojejunostomy for Gastric Outlet Obstruction: A Retrospective, Cohort Study. Surg Laparosc Endosc Percutan Tech 2018;28:e49-53.

23. Box GEP, Tidwell PW. Transformation of the independent variables. Technometrics 1962;4:531-50. [CrossRef]

24. Kaminishi M, Yamaguchi H, Shimizu N, Nomura S, Yoshikawa A, Hashimoto $M$, et al. Stomach-partitioning gastrojejunostomy for unresectable gastric carcinoma. Arch Surg 1997;132:184-7. [CrossRef]

25. Lorusso D, Giliberti A, Bianco M, Lantone G, Leandro G. Stomach-partitioning gastrojejunostomy is better than conventional gastrojejunostomy in palliative care of gastric outlet obstruction for gastric or pancreatic cancer: a meta-analysis. J Gastrointest Oncol 2019;10:283-91. [CrossRef]

26. Cai Z, Zhou Y, Wang C, Yin Y, Yin Y, Shen C, et al. Optimal reconstruction methods after distal gastrectomy for gastric cancer: A systematic review and network meta-analysis. Medicine (Baltimore) 2018;97:e10823.

27. Zong L, Chen P. Billroth I vs. Billroth II vs. Roux-en-Y following distal gastrectomy: a meta-analysis based on 15 studies. Hepatogastroenterology 2011;58:1413-24. [CrossRef]

28. Hirst A, Philippou Y, Blazeby J, Campbell B, Campbell M, Feinberg J, et al. No Surgical Innovation Without Evaluation: Evolution and Further Development of the IDEAL Framework and Recommendations. Ann Surg 2019;269:211-20. [CrossRef]

\section{ORİIINAL ÇALIŞMA - ÖZET}

\section{Malign mide çıkış obstrüksiyonu nedeniyle palyatif gastrojejunostomi uygulanan hastalarda mide bölüicü cerrahinin mide boşalmasına etkisi \\ Dr. Reyyan Yıldırım, ${ }^{1}$ Dr. Bahar Candaş, ${ }^{2}$ Dr. Mehmet Arif Usta, ${ }^{1}$ Dr. Serdar Türkyılmaz, ${ }^{1}$ Dr. Adnan Çalık, ${ }^{1}$ Dr. Ali Güner ${ }^{1}$}

${ }^{1}$ Karadeniz Teknik Üniversitesi Tıp Fakültesi, Genel Cerrahi Anabilim Dalı, Trabzon

${ }^{2}$ Karadeniz Teknik Üniversitesi Sağlık Bilimleri Fakültesi, Cerrahi Hastalıklar Hemşireliği Anabilim Dalı, Trabzon

AMAÇ: Malign mide çıkış tıkanıklı̆ı palyatif tedavisinde konvansiyonel gastrojejunostominin palyatif etkinliği tartışmalıdır. Bu çalışmanın amacı, konvansiyonel gastrojejunostomi ile mide bölücü gastrojejunostominin sonuçlarını karşısaştırmak ve malign mide çıkış tıkanıklı̆ı olan hastalarda cerrahi sonrası gecikmiş mide boşalmasını etkileyen faktörleri araştırmaktır.

GEREÇ VE YÖNTEM: Çalışma grubu midenin bölünüp bölünmeme durumuna göre konvansiyonel gastrojejunostomi ve mide bölücü gastrojejunostomi olarak iki gruba ayrıldı. Tüm demografik veriler; hasta özellikleri ve gecikmiş mide boşalma derecesi ile 30 günlük komplikasyonları içeren ameliyat sonrası sonuçlar toplandı. Klinik sonuçların karşılaştııımasının ardından, gecikmiş mide boşalması için risk faktörleri regresyon modelleri kullanılarak belirlendi.

BULGULAR: Elli üç hasta çalışmaya alındı. Otuz yedi hastaya konvansiyonel gastrojejunostomi, 16 hastaya ise mide bölücü gastrojejunostomi uygulandı. Hastaların demografik ve temel özellikleri gruplar arasında benzerdi. Konvansiyonel gastrojejunostomi grubunda I0 (\%27) hastada grade B-C gecikmiş mide boşalması mevcut iken, mide bölücü gastrojejunostomi grubunda hiçbir hastada bu durum gözlenmedi. Gruplar arasında hastanede yatış süresi ve komplikasyonlar açısından fark yoktu. Çok değişkenli regresyon analizinde uzak metastaz varlığı (OR=0.।56, \%95 GA 0.034-0.720, $p=0.017)$ ve mide bölünmesi $(O R=0.127, \% 95 G A$ 0.025-0.653, $p=0.014)$ gecikmiş mide boşalması için bağımsız faktörler olarak bulundu.

TARTIŞMA: Malign mide çıkış tıkanıklığı olan hastalarda, mide bölücü gastrojejunostomi konvansiyonel gastrojejunostomi ile karşılaştırıldı̆̆ında, mide boşalmasını iyileştirerek olumlu klinik sonuçlar sağlayabilir.

Anahtar sözcükler: Gecikmiş mide boşalması; mide bölücü gastrojejunostomi; mide çıkış obstrüksiyonu.

Ulus Travma Acil Cerrahi Derg 2020;26(5):678-684 doi: 10.14744/tjtes.2020.I4668 